\title{
Biological Relative, Paternal
}

National Cancer Institute

\section{Source}

National Cancer Institute. Biological Relative, Paternal. NCI Thesaurus. Code C132451.

Any individual related biologically to an individual's father. 